\title{
Completing Studies in Alternative Ways in Adult Education. 'Who has told me that I cannot ...?'
}

\author{
Lena Randevåg \\ Mid Sweden University \\ Sundsvall, Sweden \\ Lena Boström \\ Mid Sweden University \\ Sundsvall, Sweden
}

\begin{abstract}
Every fourth young adult in Sweden leaves upper secondary school without complete grades (Statistiska Centralbyrån, 2017). These young adults without a diploma are at risk of being marginalized ( $\mathrm{Hu}-$ go, 2007; Lundahl et al. 2015). Therefore, all attempts to support these students' needs using alternative methods to help them complete their studies are of great importance for both society and the individuals. With this study, we aim to shed light on how participants with different functional variations and overall unfavourable school experiences in a project-based alternative study program in upper secondary education perceive the factors of success. Moreover, we want to understand the project's outcome based on contextual factors. To do this, we use an abductive content analysis of project documents, field notes, and interviews with five students. Our analysis follows three steps. Firstly, we identify three major themes expressed by the participants as success factors concerning ways to attend and complete their secondary education. Secondly, we identify how contextual factors can explain the project's outcome. Finally, we draw conclusions on how motivation theory, motivation strategies, and factors in the learning environment can explain the project's outcome. The overall conclusions are (a) students in this target group need to participate in negotiations concerning their adaptation in their studies, (b) a symmetrical interpersonal relationship between teachers and students is a necessity, and (c) beneficial learning environments are essential for these students' learning.
\end{abstract}

Keywords: adult learning, alternative pedagogy, content analysis, functional variations, study motivation.

\section{Introduction}

Every fourth young Swedish student leaves the upper secondary school without completed grades (or full marks) (Statistiska Centralbyrån, 2017), and about half 
of that group carry on their studies afterwards (Friberg, Karlberg, Sundberg Lax, \& Palmer, 2015). Being a young adult who does not have an upper secondary education is the single largest risk factor for early exclusion from society. This group are also heavily overrepresented among the unemployed, social support dependents, and those who receive sickness compensation (Skolinspektionen, 2014). Without an upper secondary education, students face increased risk of marginalization and exclusion and limited chances in life for the long term. In contrast, obtaining a degree from upper secondary school is a "protection factor" and a basis for establishing oneself in society (Hugo, 2011; Statistiska Centralbyrån, 2017). Among the many reasons, students may have for not completing high school studies are school fatigue and lack of guidance or support (Statistiska Centrtalbyrån, 2017). Within this group also are many students with different functional variations and mental health, concentration, or learning problems. Many of these students have not received enough support from the school or have received it too late to be able to complete their studies. Despite the fact that special educational efforts and guidance efforts contribute to improving school results and help students with transitions, these are rarely addressed in municipal policies (Lundahl et al., 2015). Nowadays, however, there is a municipal follow-up responsibility to motivate young people up to the age of 20 to resume their studies (Utbildningsdepartementet, 2013).

Many factors affect students' study motivation and school opportunities. Some are family members' occupation and study habits (Skolinspektionen, 2014), class affiliation and grades (Skolverket, 2009, 2019), gender, and being of foreign descent (Skolverket, 2017). Many municipal representatives, though, place responsibility for the lack of motivation on the young people themselves (Lundahl et al., 2015).

Teachers and other school participants indicate that young adults without upper secondary school grades need alternative arrangements for teaching and the learning environment to have an opportunity to succeed with their studies. This neglected group has been the target of some development projects in Sweden over the past 10 years. In this study, we focus on alternative arrangements for this student group. For 2 years, the project "Dare to study again" involved young adults who had difficulty completing their studies in ordinary school systems in a municipality in which approximately $10 \%$ of the students do not pass the upper secondary school exam within 4 years. The project's successand above all, the students' own voices about this alternative form of studying gave it great value for review and analysis. Other important reasons for this study are that national studies in the field are few (Lundahl et al., 2015) and that research on the interaction between an individual and the learning environment in Swedish schools is also limited (Blomgren, 2016).

In view of the above problem picture, our overall aim for the study was to contextualize and understand the students' experiences and perceptions of crucial success factors in an alternative study structure in adult education. The research questions were as follows: 
1. What are the crucial success factors in the project from the students' perspective?

2. How can the project's outcome be understood based on contextual factors?

To explore these issues, we initially describe the theoretical frameworks that we based the study on, namely didactics for adults, motivational theory, motivational strategies, and learning environment. Then we describe the empirical starting points and methodological approach and present the results of the study. Finally, we discuss conclusions and pedagogical implications in relation to the theoretical framework. The article ends with suggestions for future research.

\section{Theoretical Framework}

The theoretical starting points for this study consist of adult didactics and study motivation. Teaching originates in an interaction between a number of different factors, such as between the teacher's didactic considerations based on various documents of control and collegial decisions on teaching and the students' performances and study motivation (Eriksson, Larsson, \& Sipos Zackrisson, 2012).

Because study motivation is multifaceted, we focused this study on the following aspects: motivation theory, motivational strategy, and learning environments. These aspects are not mutually exclusive but overlap and complement each other (Boström \& Bostedt, 2019).

\section{Didactics for Adults}

The variety of perspectives with regard to adult didactics is great, according to an international overview by Larsson (2006), who described six different types of didactics containing a variation based on how the perspectives address different problems that didactics handle. Municipal adult education (KomVux in Swedish) tradition is based on one of these types, the so-called reform didactics (Eriksson et al., 2012). Thoughts in the reform didactics include ideas that adults should be self-directed in learning, that real-life problems should be the basis for learning, that the norm for teaching ought to be that of the reflective practitioner, and that teaching should be work-integrated. Even if municipal adult education (Kom$V u x)$ draws ideas from reform didactics, Abrandt Dahlgren, Arvidsson, and Dahlgren (2012) showed that the same institutional practice might include several didactics. Larsson (2006) concluded finding any general didactics for adults is not possible. What characterizes different educational practices also shapes didactics (Larsson, 2006). Thus, the formation of teaching becomes an important factor. In this context, the way that curricula limit the teacher's space challenges the conception that the teacher is the only one shaping education. And although some see adults as self-directed and possessing the experience to be a resource for learning (Knowles, Holton, \& Swanson, 2015), adults do not unilaterally influence education (Assarsson \& Sipos Zackrisson, 2006). However, Abrandt Dahlgren et al. (2012) stressed the teacher's ability to relate to the basic didactic questions of legitimacy, selection, communication, and identity when designing teaching. Instead of just seeking explanations in frame factors or the teacher's ability to design the teaching or just starting from the adults' needs to know 
why, what, and how to study, Eriksson et al. (2012) offered a negotiating perspective based on what actually happens in a teaching practice: teaching begins with a negotiation of didactic choices between teachers, students, and sometimes, other actors. Furthermore, Eriksson et al. (2012) emphasized the teacher's knowledge of the student's way of creating meaning with his or her studies.

We believe that prerequisites for meaning creation include that they allow students to see the benefits of their studies, that activities are real, and that the activities challenge participants' perceptions. The benefits of studies include being interested or becoming interested in the studies. Seeing an activity as being real concerns teachers' treating the students as adults and the activities' being authentic and demand-filled so that the studies are similar to a job. To challenge the participants' different representations, teachers and participants must have time and opportunity to meet in different forms of communication. Common to these three meaning-creating conditions (Assarsson \& Sipos Zackrisson, 2006) is that they can facilitate interaction between teachers and participants when creating learning opportunities. Meaning-creating conditions can also relate to the question of which participant identities are possible in adult education.

Although teaching situations may appear to be different, the same type of requirement is still characteristic for the expected participant identity: to be studyinterested, change-prone, independent, and caring (Assarsson \& Sipos Zackrisson, 2005). It may also mean that adult education may not fully include identities for participants who have less study-experience or different types of functional variations or who suffer from mental illness.

\section{Study Motivation}

Motivating students is one of the greatest challenges teachers face. Students' motivation decreases with the years, according to international research (Skaalvik \& Skaalvik, 2013, 2016). Problems with study motivation exist between the individual and something else in a given situation (Aspelin, 2018).

Research presents strong evidence that motivation affects students' study results (Giota, 2013; Hattie, 2009). Motivation also affects students' concentration, endurance, and learning strategies because the more motivated students are, the more they work with tasks, adapt their learning strategies, and gradually take on more tasks that are difficult. Motivation also has an impact on the choices students make in upper secondary school regarding their eligibility for programs, optional subjects, and in-depth studies (Skaalvik \& Skaalvik, 2016). The higher the motivation, the more opportunities, and the less motivation, the fewer choices. Different student groups have different goals with their learning, which has consequences for motivation and performance. The same goes for lowperforming students, who often are critical to school's way of working, which has consequences for their motivation (Giota, 2013).

\section{Achievement Motivation Theory}

Several theories exist regarding study motivation, and they partly overlap and focus on different aspects of the phenomenon. We based this study on achievement motivation theory (McClelland, 1958), which explains and understands 
students' motivation for study from a social-cognitive perspective, which combines behaviourist and cognitive perspectives on motivation. In this study, we use the division of internal, external, and non-existent motivation (which also overlap and which we can divide into subcategories). Inner motivation is when the driving force for action is inside the human being and he or she acts for the sake of the activity itself. The actual activity provides satisfaction, commitment, and positive emotions and receives no outside feedback. The opposite, external motivation, means that a person learns something to get a reward (for example, grades, jobs, and money). The activity is a means directed towards a goal (Jakobsson, 2000). External motivation can also correlate with feedback in the present, such as encouragement and practical benefit. Controlled or autonomous external motivation can include external motivation. The former means another person controls motivation through reward, sanctions, or threat of failure. Autonomous external motivation in this context means that the student has taken on the values of the school and strives even if the activity does not bring joy. For those students who find it difficult to find motivation in school, external motivation is a tool for starting their studies. This motivation condition is the most common in school but not the optimum for lifelong learning, which is to find inner motivation (Imsen, 2006). Determining motivation through a student's behaviour is impossible. The student's reasons for an act are the only determining factor (Woolfolk \& Karlberg, 2015). A third aspect of motivation is nonexistent motivation: when students find it difficult to find motivation at school at all. In this state, they often give up, blame factors other than themselves, and simply do not see the connection between performance and results (Sjöberg, 1997).

A specific motivational theory for adult learning and motivation is hindrance motivation (Ahl, 2004), which assumes that people have an inherent desire for learning but different obstacles, such as personal events, poor school experiences, poor self-confidence, identification with a social group, incorrect pedagogy, and social structures, get in the way. If the obstacles go away, the motivational problems can also disappear. The relationship in the pedagogical meeting is crucial for students to have the opportunity to choose positive study behaviours (Aspelin, 2018; Hugo, 2007, 2011).

\section{Motivation Strategies}

Strategies to increase motivation operate from the perspective of either the teacher or the student, but the two perspectives interact with each other. To increase students' motivation, teachers need to take into account the complexity of events, groups, and students when organizing and planning (Giota, 2013). Many teaching strategies influence student motivation: task-design, autonomy, recognition, group division, evaluation, time, didactic diversity, and positive leadership in the classroom. In contrast, strategies that undermine motivation include ineffective or no feedback, lack of context, negative mood in class, overly difficult tasks, slow pace, focus on getting ready and not learning, poor planning, punitive leadership, and unattractive classrooms (Giota, 2013; Hattie, 2009; Woolfolk \& Karlberg, 2015). Paying attention to the feelings that are brought about by success and failure and to the way teachers handle these feeling at both the group and individual level is also important (Giota, 2013; Imsen, 2006; Lun- 
dahl et al., 2015). The teacher's overall didactic competence (Hattie, 2009) is crucial for students' motivation.

Students' motivation to learn also has a strong connection to their selfperception, self-worth, competence experience, and individual goals (Hugo, 2011; Wery \& Thomson, 2013). Therefore, students developing their own motivational strategies are important. Students' motivation also affects how they perceive information: if it is relevant, how much benefit they see in it, how much difficulty they experience, used working methods, what kind of feedback they receive, whether they can divide it into groups, perceived group dynamics, and many other factors related to classroom, didactic and studies (Håkansson \& Sundberg, 2012; Woolfolk \& Karlberg, 2015). The learning environment in which students are located largely influences their motivational degree (Wery \& Thompson, 2013), as described below.

\section{Learning Environments}

The learning environment shapes students' motivation for schoolwork, which they clearly show in the descriptions of their feelings and perceptions of success and failure (Blomgren, 2016). An adapted learning environment with an inclusive approach is a prerequisite for those students who have not succeeded earlier in school (Friberg et al., 2015). Learning environments can include many different perspectives on learning and its complexity. Sveriges Kommuner och Landsting (2017b) described learning environments based on three dimensions: psychological, social, and psychosocial. Ahlberg (1999) described a multifaceted picture of learning environments that include, for example, psychological, sociological, pedagogical, cognitive, perceptual, sociocultural, socioeconomic, physical, communicative, social, and organizational aspects as well as aspects of equality and democracy. Narrowing the perspective to schools includes the physical and social environments. The school's external framework as an economy and organization is a tool that influences the learning environment. More concrete in the physical and social sphere, good learning environments may include, for example, working methods, attitudes, or the classrooms' physical design, which are important factors that can contribute to creating good conditions in which all pupils can feel full participation in the activities (Evanshed, 2012).

To be able to better take responsibility for and develop lifelong learning as a student and to understand student' learning processes, teachers need knowledge and insights on how to establish good learning environments. Understanding individual differences and similarities in and about learning gives teachers respect for and opportunities to meet students in school on their terms (Evanshed, 2012; Hugo, 2007). The human being interacts with the social and physical environment, and he or she affects and is influenced by it (Björklid \& Fischbein, 2011). Teachers should view motivation in relation to the association between the student, the learning environment, and possible learning strategies (see also Blomgren, 2016). 


\section{Empirical Standpoints}

This section will address the context of the study, data collection and processing, and the design and analysis method.

\section{Context}

The researchers conducted the study within the framework of a project, "Dare to study again", in the adult education program in a small city (Sveriges Kommuner och Landsting 2017a). Adult education has courses at the primary and upper secondary level. Courses in Health education and Swedish for immigrants are also available. Students can take the courses as either distance education or regular education. The alternative structure in the studied project is based on individual and locally adapted studies with extra pedagogical support and social initiatives for the students who dare to resume their studies. The target group for the project were young adults without employment with the need for studies or vocational training. For many in the target group, different functional variations, learning difficulties, or mental illnesses have created barriers to study or to complete an education program. The premises used for the study activities comprise about $120 \mathrm{~m}^{2}$, including three small study rooms and three rooms which are the teachers' workspace. The students whom we interviewed had various types of difficulties and differences that affected their school backgrounds, including low self-esteem in studies, ADHD diagnosis, mental illness, reading and writing difficulties, concentration difficulties, and language difficulties. This constituted grounds for individual adjustments supporting their studies.

\section{Empirical data}

The empirical data consists of five student interviews (S1-S5), field notes (F), observations from eight occasions, and project documents (D1-D3). Data collection from the "Dare to study again" project took place during the period from February 2016 to January 2018. The students were also at different levels in their education and needed support in different subjects depending on which courses were lacking for them to have complete grades. The average age was 26 years, and the range was 21-37 years. Here is a short description of the five students:

Student 1 (S1) - male, born 1980, not study-motivated, low self-esteem in terms of studies, serious reading and writing difficulties,

Student 2 (S2) - male, born 1995, ADHD diagnosis, major difficulties during schooling, including mental illness,

Student 3 (S3) - male, estimated year of birth 1990, difficulties with the Swedish language and understanding of Swedish society,

Student 4 (S4) - female, born 1993, low self-esteem in terms of studies, both language- and concentration difficulties,

Student 5 (S5) - female, born 1996, ADHD diagnosis, low self-esteem in terms of studies, major difficulties in focusing on studies and mental illness in the past. 


\section{Data Collection and Processing}

Initially, one of the project researchers carried out field studies in the form of eight observations, each lasting 2-3 hours, and documented them as field notes comprising approximately four A4 pages of text in a 12-point font. The observations had the exploratory purpose of getting an idea of the content and form of everyday work in the project as well as the activities the educational provider offered. As an observer, the researcher met students and staff and was able to observe different rooms, situations, and activities. The ambition was to prepare the upcoming interviews and create an understanding of the outcome of the project's work. After the field studies, the researcher carried out five interviews lasting between 45 minutes and 1 hour, which she recorded digitally and conducted during one day. The interviews began with the researcher informing the students about the purpose of the interview and the principles of research ethics.

For this study, we followed the Research Council's principles for good ethical research within social sciences and took into account the ethical standards on information consent, confidentiality, and utilization requirements (Vetenskapsrådet, 2017). We obtained informed consent from all potentially involved teachers and students, who had received information about the study before start-up, about our presence, and about the right to withdraw from the study. All interviewees gave consent to participation in the study. We transcribed the interviews with the students and analysed the content through deductive content analysis (see the subchapter below). We used the field notes and project documents in the subsequent analysis where we compared research questions against the empirical data.

\section{Design and Analysis Methods}

We characterize the study's method of analysis as a hybrid of content analysis (Fereday \& Muir-Cochrane 2006; Rising Holmström, Häggström, \& Kristiansen, 2015), which started with deductive analysis and then switched to inductive analysis, which we linked to the previously mentioned theoretical starting points in the results. The design makes combining theoretical perspectives and empirical data possible (Whittemore \& Knafl, 2005), which also makes the analysis difficult to process but, if implemented well, more comprehensive. The theoretical codes derive from the theories of motivation (Ahl, 2004; McClelland, 1958), motivation strategies (Giota, 2013; Hugo, 2011), and didactics for adults (Abrandt Dahlgren et al., 2012; Aspelin, 2018; Assarsson \& Sipos Zackrisson, 2005, 2006; Eriksson et al., 2012; Hugo, 2011; Larsson, 2006).

We initially used a qualitative research design with targeted content analysis (Hsieh \& Shannon, 2005) to be able to answer the research questions. Deductive analysis (theory-driven) assumes that we determined a theoretical framework in advance of analysing interview material, which we describe as using that themes based on existing theories and research results (Mayring, 2000). Deductive content analysis utilizes a more structured process than predictive coding. This form of content analysis enables comparisons of results from previous research and discussion of the results from different theoretical perspectives (Elo \& Kyngäs, 2008). One impact of starting deductively is the ability to support or further develop previous knowledge or theories. Based on these three frameworks, we 
developed a categorization matrix (see Table 1) that we used in a structured and systematic way.

To analyse the contents of the interviews, project documents, and field notes, we used an inductive content analysis. In other words, the analysis switched to an inductive approach (see Figure 1). With four themes, we developed the categorization matrix and sorted all data according to the theme to which they belonged. We used the content analysis to examine the interview responses for a more nuanced picture of the students' perceptions and to examine the project documents and field notes for contextual understanding of the project's outcome.

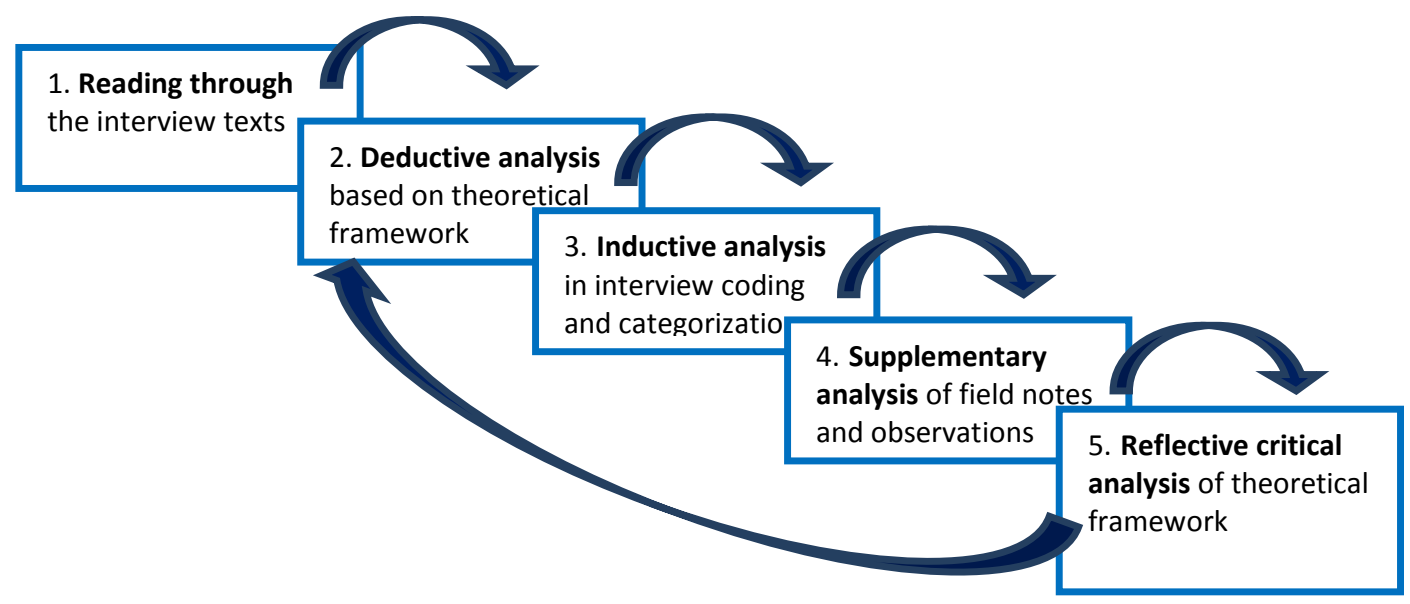

Figure 1: Image of the analysis process inspired by Rising Holmström et al. (2015).

Then followed an inductive sorting of the empirical material. Thus, the texts "talk freely" within each theme and generate categories that describe this. After a close reading, we condensed the parts of the text that expressed identifiable ideas or standpoints (measuring units) through categories within each theme. Then we examined the empirical content methodically, interpreted the texts gradually, and classified the data for distinguishing patterns. The contentanalytical model finds distinctive categories then delimits and, if possible, specifies them (Graneheim \& Lundman, 2004). We broke down the empirical material into meaning-bearing units, which we condensed into shorter sentences and then abstracted into categories that describe the content of the opinion units. Next, we combined categories with similar content into themes, which we derived from the research questions (Bryman, 2014). To make the analysis transparent, we combined the condensed units, categories, and themes in an analysis scheme (see example in Table 1). In the results section, we interpret these categories and present them in their respective themes with some speaking quotes. 
Table 1: Example of the Analysis Schedule

\begin{tabular}{llll}
\hline Meaning-making unit & Condensed unit & Categories & Themes \\
\hline $\begin{array}{l}\text { We have made a plan; } \\
\text { we mostly go to what I } \\
\text { think when it is suit- } \\
\text { able (S4). }\end{array}$ & $\begin{array}{l}\text { Clear structure but } \\
\text { still participation that } \\
\text { contributes to making } \\
\text { it possible to study }\end{array}$ & $\begin{array}{l}\text { Participation } \\
\text { and clarity }\end{array}$ & $\begin{array}{l}\text { Structure and } \\
\text { flexibility }\end{array}$ \\
& & & \\
\hline $\begin{array}{l}\text { They kind of see the } \\
\text { person (S1). }\end{array}$ & $\begin{array}{l}\text { The teachers show } \\
\text { commitment in the } \\
\text { response. }\end{array}$ & $\begin{array}{l}\text { Affiliation and } \\
\text { trust }\end{array}$ & Authenticity \\
\hline $\begin{array}{l}\text { f.. the structure, the } \\
\text { calm, the accessibility } \\
\text { of teachers as well as } \\
\text { the opportunity to sit } \\
\text { for oneself ... and still } \\
\text { have ... close to teach- } \\
\text { ers (S2) }\end{array}$ & $\begin{array}{l}\text { Alternative ways of } \\
\text { conducting studies are }\end{array}$ & $\begin{array}{l}\text { Accessibility and } \\
\text { time create secu- } \\
\text { rity. }\end{array}$ & $\begin{array}{l}\text { Adaptions of } \\
\text { the studies }\end{array}$ \\
& & & \\
\end{tabular}

The described analysis process was not linear but had an iterative character; that is, the process moved back and forth between the different phases. We carried out the data processing as reflective dialogues between the texts and ourselves. The various themes gave rise to subheadings in the study's results. We coded the participants in the transcribed material with the numbers S1-S5 (S for student) to more easily distinguish them during the processing of the data set. We coded the project documents as D1-D3 and gave field notes the code F.

To ensure reliability and credibility in the study, we examined all empirical data then read each other's analyses, compared the outcome data, and through subsequent discussion and examination, reached agreement. Next, we subjected the condensations and categories to critical discussion, resulting in some modifications, and then analysed and labelled the categories by themes. After reading the analysis in its entirety, we discussed and compared the results. The interviews as a whole served as a reference point throughout the analysis process when we needed deeper understanding of the units, categories, and themes. We discussed the interaction between categories and themes to achieve consensus. To create credibility and generalisability for the results, we have reported our methodological approach, categorization, and method of analysing empirical data in an appropriate way for obtaining holistic understanding of the content.

\section{Results and Analysis}

To get an answer to the first research question, we used a content analysis (Hsieh \& Shannon, 2005; Krippendorff 2019), which utilizes finding clearly distinct categories then delimiting and, if possible, specifying them. Here in the results section, we present these categories in their respective themes with some 
speaking quotes. Through analysis of the empirical material, we received three themes: structure and flexibility (with the categories clarity and participation), adaptation of the studies (with the categories availability, time, and security), and authenticity (with the categories affiliation and trust). Themes with associated categories are central to understanding the crucial success factors in the project from the participants' perspective.

\section{Structure and Flexibility}

One clear theme is the combination of structure and flexibility. The actual organization of the study is thus dependent on the combination of structure and flexibility. The categories we found are clarity and participation. Clarity means that the students know what times during which days the teachers are available to them or how they otherwise can get in touch with the teachers via text and email; they also know how to get access to a quiet study place. Overall, clarity contributes to a supportive structure in which each student knows what to do, or as one respondent put it, "You do what you should do, and you are not interrupted by others" (S5).

Flexibility is primarily evident in the perceived participation, which involves an actual influence on how the studies are set up and implemented. The starting point is that the student should be able to influence the organization of the studies: "We have made a plan: mostly do what I think is appropriate" (S4). Participation is thus shown by the student's being able to influence and include the target picture for the studies.

Structure provides a clarity that is negotiable for each individual and together with flexibility, provides opportunities to study: "The flexibility makes it possible to get a structure that suits me rather than to get this high school every day, like ... well, to really bend and turn so that it fits me" (S2). However, the combination of structure and flexibility is just one of the success factors, according to the students. The actual adaptation of the studies is also an important factor, which the next theme makes clear.

\section{Adaptation of the Studies}

The students use terms of teachers' accessibility, time, and security to describe the adaptation that they require to be able to complete individual courses or their education as a whole. Accessibility does not mean constant monitoring, but more that teachers are available during the times they set aside and only if and when the student feels that he or she needs support and help: "Accessibility to teachers as well as the opportunity to sit for oneself ... and still have ... close[ness] to the teacher" (S2).

Time is also part of the adaptation. All interviewees feel that not only do they have access to teachers, but also that the time they receive from the teachers in the form of support and help is larger and more individualized than when the teaching is traditional. "Well, it feels like the teachers have more time for you ... yes it is ... here I get access to help in a completely different way ... because there's not 20 other students" (S1). 
However, time might as well be a matter of a teacher's not hurrying or rushing through content, or as one interviewee says, "Now that I have been taught that it may take time, because it [the results of learning] must stick too, I've become much more calm" (S4), which leads to a sense of security when studying.

The sense of security comes from knowing that there is a place to go where the learning environment is peaceful and quiet, where the student is not anonymous to the teacher and can work at her/his own pace. "You do not become one in the mass as it feels that it gets easily up there like" (S3). Here, the interviewee is trying to explain the difference between the traditional form of teaching, which usually takes place in Swedish upper secondary classes, and the way the project organizes teaching. The security that the study situation creates through the teachers' accessibility, when needed, and the time they allocate to support each individual is also closely related to the next theme, authenticity, which refers to others seeing a person as an individual.

\section{Authenticity}

The theme of authenticity means that a student does not have to play a role or dissemble in any way. Feeling both seen and understood reinforces one's sense of authenticity. "They see the person in some way" (S1). Within this theme are two categories of crucial importance for the successful completion of the studies.

The category that we called affiliation closely links to the feeling of authenticity because each person is allowed to be just the way he or she is: "But I can be myself (...) I can be who I am while I study" (S4). The affiliation consists of the students' feeling that the study activity in which they participate is for them and that they belong there, which contributes to the studies being perceived as meaningful on the individual level. "So now when I have started studying, I've become a bit like well, I might just fix this anyway; I might be much better than I thought I was" (S5).

The affiliation is also linked to the category of trust, which is about the teacher's trust in the student as well as the student's confidence in his or her ability to study. The teacher's confidence can at best develop the student's self-confidence, which the following quotes show:

"The most important thing is that I think I should succeed. ... But I think that the way it has been lately, the teachers believe more in me than I believe in myself." (S5)

“But this goal, breaking out of your situation... like you actually built up a notion like, no, no studies, no studies... and then to take that step. Well, OK, why wouldn't I be able to? I have to be able to do it like everyone else? What have I like ...Who has told me I'm not able to; why has it become so? Then the project was very good to come to because I felt like, here's where I can get motivation. " (S1)

Apparent in the above quotes is the power that exists in discovering one's trust and belief that one should be able to cope with and complete the studies. The 
interviewees stated that the fact that teachers give confirmation and show confidence in the students' ability defines as a very important success factor.

\section{Project Outcome Based on Contextual Factors}

To answer the second research question regarding the project's results, we used a content analysis for the empirical material here, too. The overall outcome is about the execution of the project, motivation-promoting strategies, and an inclusive learning environment.

Both students and teachers have successfully experienced study planning. What the teachers in particular highlight is the width of the support. Getting individual support in different subjects has been possible within the adult education program's ordinary activities, such as by clarifying assignments, and in entire courses by adjusting the pace of study and vocational training through distance education, by trying out studies with a planned, gradual step-by-step introduction, and by developing study strategies to find the students' abilities and strengths. According to final project report the approach that uses the categories of clarity, participation, accessibility, time, security, belonging, and trust, the students feel that the project has contributed very much to their study success.

The teachers also emphasize their relationship to the students: "The students who come to the project must be offered a professional approach, a commitment to their individual needs, and the possibility of flexible learning" (F).

One of the motivation-promoting strategies that teachers have conducted within the project according to project documents (D1, D2) is working from an inclusive approach in which one of the project's goals of increased accessibility was particularly important. With regard to the project's goal of increased accessibility to studies, the students perceive the project's study structure as positive compared to traditional study arrangements. An important result is greater proximity to study and vocational guidance counsellors for collaboration that makes the students feel a sense of confirmation and that meets their need for one more personalized entry into studies (S3). Other prominent motivational factors are students, individually structured tasks, a coaching approach, and mediation of future faith $(\mathrm{F})$.

In regards to the program's inclusive learning environment, the pedagogical adaptation of students' individual study pathways and the physical learning environment are particularly important. The project's ambition is not for people to perceive it as a place where one goes when one fails but instead as a community in which one participates and where one's differences are assets (D1, D2, F). The ambition that the learning environment should be permissive and personal also correlates to an adaptation for learning and an inclusive learning environment, or as one of the teachers put it, "The student first and foremost! You can! Dare!" (F). Collaboration and dialogue with other teachers at Adult Education and with study and vocational guidance counsellors have also helped to draw attention to students who need extra adaptations or changes in their individual study plans (D3). The fact that the teachers involved in the project have also 
scheduled lessons and courses in the upper secondary school system has greatly contributed to the possibilities for collaborating and adapting the studies to the project's target group.

The program's leaders have organized the physical learning environment so that individual adaptation is possible based on the need for a quiet study site, individual work, tutoring from teachers, and joint work in smaller groups. Teaching materials and other didactic material are also available for the students $(\mathrm{F})$.

\section{Conclusions and Educational Implications}

The conclusions that we draw from interpreting our content analysis mainly concern three themes: authenticity, structure combined with flexibility in the teaching structure, and adaptation of the study structure. These themes are not mutually exclusive but overlap to some extent. The three themes concern important questions about: who or what should be the focus of the teaching, the one learning something, or the one who teaches. Many statements in our empirical evidence indicate that when teachers "just do their thing and teach" (S2), the purpose of the lesson is only to convey something and not necessarily to teach the pupil something. The students we interviewed had experienced just that when they attended the traditional upper secondary lessons. One explanation could be the one Assarsson \& Sipos Zackrisson (2005) offered: Adult education accepts only one participant identity, namely the one being study-interested, changeprone, independent, and caring. When they attended traditional lessons, the students in our study did not experience any form of negotiation regarding the adaptation of studies or the focus of teaching about which Eriksson et al. (2012) wrote. Lessons and studying in the project, however, included rich opportunities for negotiating time, the flexibility of designing an individual study plan, and the support of caring teachers. This also enabled the individual motivation of the students to be triggered in a better way (see Aspelin, 2018). Regarding the adaptation of studies, the question is how large the organizational possibilities are to be able to make the adjustments required for each student to have the opportunity to learn in, for example, smaller teaching groups in which resources are available to make greater individual adaptations to the studies (see also Hugo, 2011). Furthermore, Hugo (2011) referred to the problems in schools as a fundamental hypothesis that all people learn and gain motivation in the same way, which has no support in research. Our result is in line with Hugo's (2011) study, which leads us to the area that concerns roles in teaching.

The traditional roles of teacher and student do not seem to support students' learning, especially for those students with previous negative school experiences. Since motivating students is one of the greatest challenges teachers face (Skaalvik \& Skaalvik, 2013, 2016) this project seemed to give teachers the opportunity to meet this challenge in a constructive way. A clearer symmetrical interpersonal meeting in which the teacher is engaged, respects, and cares for each student's situation appears in our analysis as a necessity. According to Hugo (2011), meaningful learning is dependent on students' experiencing meaningfulness in terms of both content and relationships. This is consistent with our result regarding authenticity in that way the students in the project felt they could be 
themselves when studying, and still be part of a community in which the teachers' participation contributed to meaningful studies. Assarsson and Sipos Zackrisson (2006) and Eriksson et al. (2012) also showed this. Hugo (2012) also stressed that the way in which the teacher is able to simultaneously relate to subject content and the student's experiences is thus crucial for learning to take place.

Because the learning environment requires a high degree of adaptation, a few of the many aspects to take into account are the mental, social, and psychosocial dimensions (Sveriges Kommuner och Landsting, 2017b). However, we want to add the meaning of the physical learning environment (Blomgren, 2016; Wery \& Thompson, 2013). The project seems to fulfil many of the aspects of Ahlberg's (1993) learning environment theory, such as the cognitive and perceptual (support for understanding task descriptions), socioemotional (belonging to a community and being seen as an individual), sociocultural (confirmation of life experience), equivalence and democracy (being seen as an agent), and communicative and linguistic aspects (prerequisites for the student's understanding).

However, we feel the need to question how staff who do not even participate can perceive the execution of a project that requires collaboration between projects and ordinary activities as an obstacle, even if other people perceive the project as a necessity for students' learning (Hugo, 2012). Here, we do not want to blame previous teachers but point out the fact that the traditional way of organizing adult education may not be optimal for the project's target group. Previous research on didactics for adults indicated that designing a specific didactics for adults is not possible. The didactics begin in each new teaching situation, according to Larsson (2006), and as a result of a negotiation between the teacher, student, and learning environment (Eriksson et al., 2012). Regarding the context in which the teachers have carried out the project, its contextual factors can very well affect the view of both the educational assignment and the student $(F)$.

Our assessment is that the project has created a basis for good learning environments (see also Evanshed, 2012) that feature many positive aspects, such as common values, individual working methods, student participation, and pedagogical relations competence. Despite the structural obstacles that may exist, for example, organization, finances, and physical limitations, leaders have implemented the project, and it is now permanent.

Motivation-promoting strategies include both the teacher and students' perspective. However, a complex interaction occurs between the two (Giota, 2013; Skaalvik \& Skaalvik, 2011, 2016; Wery \& Thompson, 2011), and reading out the students' individual motivation strategies is not yet possible. The motivationpromoting strategies that arise in the project as a whole are a cognitive inclusive learning environment (D1) and relational aspects such as trust, respect, and the teachers' conscious approach to the project's target group (Ahl, 2004; Hugo, 2011, 2012). 
The motivational theoretical perspective is particularly evident in the students' progress of study (S1-5) from non-existent to external controlled to external autonomous and in some cases to internal autonomous motivation (Imsen, 2006; Sjöberg, 1997; Woolfolk \& Karlberg, 2015). In this project, the students have embraced the value of studies and made an effort in their studies for their own future and success. In this project, the school has used autonomous external motivation-promoting structures, which can explain the nuance of Skaalvik and Skaalvik's (2013) criticism regarding external motivation. The way the staff carried out the project managed and counteracted any obstacle motivation (Ahl, 2004) that may exist for adult learning in this project.

In conclusion, the focus ought to be on the person who wants to learn, which becomes essential for the students who for various reasons have not been able to complete their high school studies, especially because a completed education is a protection factor against social exclusion (Utbildningsdepartementet, 2013). If young adults are to be able to carry out their studies, society needs alternative learning and teaching methods in an inclusive learning environment. Perhaps those can give more young adults the opportunity to start, resume, or complete their high school studies while maintaining self-esteem, confidence in their own abilities, and a good foundation for lifelong learning.

\section{Research Recommendations}

Firstly, more researchers need to study young adults without completed education and their study motivation, because this study examined only one case with a smaller population. One important area is to perform a follow-up study of the same student group regarding the individual study strategies to which the students have been dedicated and have developed and maintained over time. Secondly, trying to perform an in-depth analysis of the tools in the crucial relational competence is important. What is important in the relationship between teacher and student that contributes to its positive outcome? It is all about value, attitude, verbal and nonverbal communication, and leadership. Thirdly, engineering longitudinal studies on the factors that otherwise affect students' motivation and opportunities, such as class affiliation, gender, and ethnicity, is important to better understand structural influencing factors.

\section{References}

Abrandt Dahlgren, M., Arvidsson, J., \& Dahlgren L.-O. (2012). De eviga didaktiska frågorna och de nya: Möten i vuxenstudier [The eternal didactic questions and the new ones: Meetings in adult studies]. In I. M. Abrandt Dahlgren \& I. Carlsson (Eds.), Lärande på vuxnas vis [Learning in adults way] (pp. 69-77). Lund: Studentlitteratur.

Ahl, H. (2004). Motivation och vuxnas lärande: En kunskapsöversikt och problematisering [Motivation and adult learning: An overview of knowledge and problematization]. Stockholm: Myndigheten för Skolutveckling.

Ahlberg, A. (1999). Lärande och delaktighet [Learning and participation]. Lund: Studentlitteratur.

Aspelin, J. (2018). Lärares relationskompetens [Teachers' relationship competence]. Stockholm: Liber. 
Assarsson, L., \& Sipos Zackrisson, K. (2005). Iscensättande av identiteter i vuxenstudier [Identification of identities in adult studies]. Linköping: Linkoping studies in education and psychology 103.

Assarsson, L., \& Sipos Zackrisson, K. (2006). Möten i vuxenstudier: Om undervisning och deltagaridentiteter. [Adult study meetings: About teaching and participant identities]. In I. S. Larsson \& L.-E. Olsson (Eds.), Om vuxnas studier [About adults 'studies] (pp. 135-161). Lund: Studentlitteratur.

Björklid, P., \& Fichbein, P. (2011). Det pedagogiska samspelet [The educational interaction]. Lund: Studentlitteratur.

Blomgren, J. (2016). Den svårfångade motivationen: Elever $i$ en digital lärmiljö [The elusive motivation: Students in a digital learning environment] (Doctoral dissertation). Göteborg: Göteborgs Universitet.

Boström, L., \& Bostedt, G. (2019). Studiemotivation $i$ gymnasieskolan? Elevers och lärares perspektiv på dessa utmaningar och möjligheter [Study motivation in upper secondary school? Students' and teachers' perspectives on these challenges and opportunities]. Unpublished manuscript. Sundsvall: Mid Sweden University.

Bryman, A. (2014). Samhällsvetenskapliga metoder [Social science methods]. Stockholm: Liber.

Elo, S., \& Kyngäs, H. (2008). The qualitative content analysis. Journal of Advanced Nursing, 62(1), 107-115. https:/ / doi.org/10.1111/j.1365-2648.2007.04569.x

Eriksson, L., Larsson, S., \& Sipos Zackrisson, K. (2012). Hur formas egentligen vuxnas undervisning? [How is the education of adults really formed]. In I. M. Abrant Dahlgren \& I. Carlsson (Eds.), Lärande på vuxnas vis [Learning in adults way] (pp. 79-99). Lund: Studentlitteratur.

Evanshed, P. (2012). Goda lärmiljöer i skolan [Good learning envoriments in school]. In I. G. Kragh-Müller (Ed.), Goda lärmiljöer för barn [Good learning envoriments for children] (pp 70-82.). Lund: Studentlitteratur.

Fereday, J., \& Muir-Cochrane, E. (2006). Demonstrating rigor using thematic analysis: A hybrid approach of inductive and deductive coding and theme development. International Journal of Qualitative Methods, 5(1), 80-92. https://doi.org/10.1177/160940690600500107

Friberg, P., Karlberg, M., Sundberg Lax, I., \& Palmer, R. (2015). Hemmasittare och vägen tillbaka: Insatser vid långvarig skolfrånvaro [Home-schooled students and the way back]. Riga, Latvia: Livonia Print.

Giota, J. (2013). Individualisering i skolan: Vilken, varför och hur [Individualization in school: Who why, and how?] (Vetenskapsrådets Report Series No. 3). Stockholm: Vetenskapsrådet.

Graneheim, U. H., \& Lundman, B. (2004). Qualitative content analysis in nursing research: Concepts, procedures and measures to achieve trustworthiness. Nurse Education Today, 24(2), 105-112. https:/ / doi.org/10.1016/j.nedt.2003.10.001

Håkansson, J., \& Sundberg, D. (2012). Utmärkt undervisning: Framgångsfaktorer $i$ svensk internationell belysning [Excellent teaching: Success factors in Swedish international lighting].Stockholm: Natur \& Kultur.

Hattie, J. (2009). Visible learning: A synthesis of over 800 meta-analyses relating to achievement. New York, NY: Routledge. https://doi.org/10.4324/9780203887332

Hsieh, H.-S., \& Shannon, S. (2005). Three approaches to qualitative content analysis. Qualitative Health Research, 15(9), 1277-1288. https:/ / doi.org/10.1177/1049732305276687

Hugo, M. (2007). Liv och lärande i gymnasieskolan: En studie om elevers och lärares erfarenheter $i$ en liten grupp på gymnasieskolans individuella program [The way toward knowledge and competence for seven underachievers in upper secondary school] (Doctoral dissertation). Jönköping: Jönköping School of Education and Communication.

Hugo, M. (2011). Från motstånd till framgång: Att motivera när ingen motivation finns [From resistance to success: Motivating when there is no motivation]. Stockholm Liber. 
Hugo, M. (2012). När skolans lärande saknar mening [When school learning is meaningless]. In L. Mathiasson (Ed.), Uppdrag lärare: En antologi om status, yrkesskicklighet och framtidsdrömmar [Assignment teacher: An anthology on status, professional skills and future dreams (pp. 31-38). Stockholm: Lärarförbundets förlag.

Imsen, G. (2006). Elevens värld: Introduktion till pedagogisk psykologi [The student's world: Introduction to educational pshychology. Lund: Studentlittertur.

Jakobsson, A. K (2000). Motivation och inlärning ur ett genusperspektiv [Motivation and learning from a gender perspective] (Doctoral dissertation). Göteborg: Göteborgs Universitet.

Knowles, M., Holton, E., III, \& Swanson, R. (2015). The adult learner (8th ed.). Oxford, England: Elsevier.

Krippendorff, K. (2019). Content analysis. An introduction to its methodology. London: Sage.

Larsson, S. (2006). Didaktik för vuxna: Tankelinjer i internationell litteratur [Didactics for adults: Thoughts on international literature]). Stockholm: Vetenskapsrådets rapportserie 12:2006.

Lundahl, L., Lidström, L., Lindblad, M., Lovén, A., Olofsson, J., \& Öst, J. (2015). Osäkra övergångar [Uncertain transistions]. Resultatdialog 2015 (pp. 107-116). Stockholm: Vetenskapsrådet.

Mayring, P. (2000). Qualitative content analysis. Qualitative Social Research, 1(2), 44-68.

McClelland, D. C. (1958). Methods of measuring human motivation. In J. W. Atkinson (Ed.), Motives in fantasy, action, and society (pp. 7-42). Princeton, NJ: D. Van Nostrand.

Rising Holmström, M., Häggström, M., \& Kristiansen, L. (2015). Skolsköterskans rolltransformering till den hälsofrämjande positionen [School nurses' role transformations to the health-promotion position]. Nordic Journal of Nursing Research, 25(4), 210-217. https://doi.org/10.1177/0107408315587860

Sjöberg, L. (1997). Studieintresse och studiemotivation: En analys av de grundläggande faktorerna [Study interest and study motivation: An analysis of the basic factors . Stockholm: Institutet för Individanpassad Skola.

Skaalvik, E. M., \& Skaalvik, S. (2013). School goal structure: Associations with students' perceptions of their teachers as emotionally supportive, academic self-concept, intrinsic motivation, effort, and help seeking behaviour. International Journal of Educational Research, 61, 5-14. https://doi.org/10.1016/j.ijer.2013.03.007

Skaalvik, E. M., \& Skaalvik, S. (2016). Motivation och lärande [Motivation and learning]. Stockholm: Natur \& Kultur.

Skolinspektionen. (2014). Unga riskerar att falla mellan stolarna [Young people at risk of falling between the cracks] (Skolinspektionens Report No. 7). Stockholm: Skolinspektionen.

Skolverket. (2009). Vad påverkar resultaten $i$ svensk grundskola? Kunskapsöversikt om betydelsen av olika faktorer: Sammanfattande analys [What affects the results of Swedish compulsory schools? Knowledge overview regarding the importance of various factors: Summary analysis]. Stockholm: Skolverket.

Skolverket. (2017). Skolverkets lägesbedömning 2017 [The Swedish National Agency for Education's 2017 situation assessment] (Report No. 455). Stockholm: Skolverket.

Skolverket. (2019). Redovisning av Skolverkets uppdrag om att genomföra verksamhetsnära insatser för att förebygga avhopp frän gymnasieskolan [Reporting the Swedish National Agency for Education's mission to carry out operations-related initiatives to prevent dropouts from upper secondary school] (Dnr 7.2.1.-2016:32).

Specialpedagogiska Skolmyndigheten. (SPSM). (2016). D1. Projektbeskrivning [Project description].

Specialpedagogiska Skolmyndigheten. (2017). D2, Delredovisning [Interim reporting].

Specialpedagogiska Skolmyndigheten. (2018) D3. Slutredovisning [Final report]. 
Statistiska Centralbyrån [SCB]. (2017). Utbildning och arbete: Unga utanför? Så har det gått på arbetsmarknader för 90-talister utan fullföljd gymnasieutbildning [Education and work: Young outside? Results for 90 talented students who have not completed upper secondary education] (Theme Report No. 4). Stockholm: Statistiska Centralbyrån.

Sveriges Kommuner och Landsting [SKL]. (2017a). Kommungruppsindelning 2017: Omarbetning av Sveriges kommuner och landstings kommunindelning [Municipal group division 2017: Recast of Sweden's municipalities and county-council municipal division]. Stockholm: SKL

Sveriges Kommuner och Landsting [SKL]. (2017b). Olika är normen: Att skapa inkluderande lärmiljöer $i$ skolan [Different is the norm: Creating inclusive learning environments in school]. Stockholm: SKL.

Utbildningsdepartementet. (2013). Ungdomar utanför gymnasieskolan: Ett förtydligat ansvar för stat och kommun [Young people outside of upper secondary school: A clarification of the responsibilities for states and municipalities] (SOU Report No. 13). Stockholm:. Retrieved from https:/ / www.regeringen.se/49b70e

Vetenskapsrådet. (2017). Good research practice. Stockholm: Vetenskapsrådet.

Wery, J., \& Thomson, M. (2013). Motivational strategies to enhance effective learning in teaching struggling students. British Journal of Learning Support, 38, 103-108. https:// doi.org/10.1111/1467-9604.12027

Whittemore, R., \& Knafl, K. (2005). The integrative review: Updated methodology. Journal of Advanced Nursing, 52, 246-253. https://doi.org/10.1111/j.13652648.2005.03621.x

Woolfolk, A., \& Karlberg, M. (2015). Pedagogisk psykologi [Educational psychology]. London, England: Pearson. 